\title{
Modelling hydrological impacts of agricultural expansion in two macro- catchments in Southern Amazonia, Brazil
}

Article

Accepted Version

Lamparter, G., Nobrega, R., Kovacs, K., Amorim, R. S. and Gerold, G. (2018) Modelling hydrological impacts of agricultural expansion in two macro-catchments in Southern Amazonia, Brazil. Regional Environmental Change, 18 (1). pp. 91-103. ISSN 1436-3798 doi: https://doi.org/10.1007/s10113016-1015-2 Available at https://centaur.reading.ac.uk/75081/

It is advisable to refer to the publisher's version if you intend to cite from the work. See Guidance on citing.

To link to this article DOI: http://dx.doi.org/10.1007/s10113-016-1015-2

Publisher: Springer Berlin Heidelberg

All outputs in CentAUR are protected by Intellectual Property Rights law, including copyright law. Copyright and IPR is retained by the creators or other copyright holders. Terms and conditions for use of this material are defined in the End User Agreement.

\section{www.reading.ac.uk/centaur}


Central Archive at the University of Reading

Reading's research outputs online 
Modelling hydrological impacts of agricultural expansion in two macro-catchments in Southern Amazonia, Brazil

Dr. Gabriele Lamparter ${ }^{1}$, glampar@gwdg.de Rodolfo Luiz Bezerra Nobrega ${ }^{1}$, rnobreg@gwdg.de Kristof Kovacs ${ }^{1}$, kkovacsgwdg.de

Dr. Ricardo Santos Amorim², rsamorim@ufmt.br Prof. em. Gerhard Gerold ${ }^{1}$, ggerold@gwdg.de

${ }^{1}$ Department of Physical Geography, University of Göttingen, Germany

${ }^{2}$ FAMEVZ (Faculdade de Agronomia e Medicina Veterinária), UFMT, Cuiabá, Brazil

\author{
Gabriele Lamparter \\ Institute of Geography, \\ Department of Physical Geography \\ University of Göttingen \\ Goldschmidtstr.5 \\ 37077 Göttingen \\ 0049-551-308026 \\ glampar@gwdg.de
}

Abstract:

This study presents the setup, calibration, validation and scenario application of the Soil and Water Assessment Tool (SWAT) for two contrasting macro-catchments along the Amazon agricultural frontier in the federal states of Pará and Mato Grosso, Brazil. Calibration and validation of the model is realised for the periods of the most intensive deforestation and agricultural expansion. In order to give consideration to the rapid, however gradual nature of land use change, the model implements an annual land use update combined with a land use dependent soil parameterization of the upper most soil layer. The comparison of these results with the results of a setup with a steady land use distribution shows distinct improvements of the prediction quality. Discharge prediction improves through the application of gradual land use change in the model by $12 \%$ for a $1.8 \%$ deforestation rate per year and $1.2 \%$ for a deforestation rate of $0.7 \%$ per year. Consequently, the validated models are applied to four land use scenarios for the period 2026 to 2035. Scenario simulation results show effects on the water balance proportional to land use change. Further, the changes in the water balance follow clear seasonal patterns with highest hydrological effects due to land use change during the rainy season in both catchments. Overall, with continuous deforestation peak discharge increases. Further, the conversion of native to pasture has the highest impact on the water balance. For example, monthly discharge in the rainy season increases by up to $24 \%$ for a $13 \%$ conversion of Cerrado savannah into pasture.

Keywords: hydrological catchment model, SWAT, water balance components, land use change, land use update, land use and climate scenarios, Amazon agricultural frontier

Length: Abstract: 252, Text body: 5628 words, References: 2589 words, TOTAL: 8609

Figures: 4, Tables: 3 
1. Introduction:

The ever growing global demand for commodities rapidly pushes the agricultural frontiers around the world further into pristine nature and causes intensification on already existing farmland (Lambin et al., 2001). This is connected to changes in the hydrological balance. For example many studies find that deforestation leads to an increase in discharge (Q, D'Almeida et al., 2007; Davidson et al., 2012), higher floods and more severe water scarcity (Bruijnzeel, 2004; D'Almeida et al., 2007; Fearnside, 2007; Rodrigues et al., 2009). Also other effects, such as changes in the seasonality and the reduction of storage capacity, are frequently reported (Bosch and Hewlett 1982). These changes are further alarming due to their potential to fuel problems connected to the effects of Climate Change (CC, Davidson et al., 2012; Miles et al., 2006). Still, responses to Land Use Change (LUC) are highly variable and depend on the spatial heterogeneity of land use and soil characteristics (Almeida et al. 2006 and 2007). Therefore, it is not surprising that effects of current and future LUC on the hydrological balance, especially of macro-catchments, often remain poorly understood (Bruijnzeel, 2004; Coe et al., 2009; De Roo et al., 2001; DeFries and Eshleman, 2004; Price, 2011).

The largest agricultural frontier with historic and current rapid LUC is located in Southern Amazonia in Brazil (Arima et al., 2011; Fearnside, 2005, 2007). Figure 1 shows the natural vegetation of Brazil, the national highway BR-163 and the Amazon agricultural frontier. Due to its favorable climate for rainfed agriculture, Cerrado - the Brazilian savannah - is under extreme pressure from LUC (Beuchle et al., 2015; Miles et al., 2006). Historically, the deforestation of Cerrado vegetation was the most important source of new farmland in Brazil. Now, the Amazon agricultural frontier expands further towards the North through deforestation of rainforest (Arima et al., 2011), a process boosted by the accessibility through new roads (Wertz-Kanounnikoff, 2005). The ongoing paving of the BR-163 in Central Brazil lead to these typical frontier colonisation processes since the 1990s (Fearnside, 2005).

Only a few macro-catchment studies in the Cerrado biome evaluate the hydrological effects of this comprehensive LUC. However, these studies consistently show a rising trend in $Q$ with deforestation. For example, Costa et al. (2003) showed an increase of $Q$ for the Tocantins River (of which the das Mortes River is a tributary) and an analysis of decadal runoff by Guzha et al. (2013b) showed a rise in runoff between 1968 and 1987 for the das Mortes River at Toriquejé (which coincides with 40\% Cerrado removal). Macro-catchment LUC research in the rainforest biome is more common. However, these studies show contradictory results regarding hydrological effects (Coe et al., 2009; Lima et al., 2013).

Hydrological models aid the understanding and enable the prediction of changes in the water balance components (WBC) due to future development. However, a reliable prediction of hydrological responses depends on an accurate formal model description of the relevant processes (Beven, 2010), e.g. processes connected to LUC. Typically, the long-term effects of LUC on hydrology are investigated with models calibrated with a steady land use distribution, which is subsequently applied to scenarios with a different and again steady land use distribution (Coe et al., 2009). Here, parameters connected to the different vegetation or land use types of the calibration and scenario periods are determined prior to the model application. This means that hydrological effects of LUC are present in these parameters. Hence, the effects of LUC in a scenario application is predetermined and not tested with observed effects of LUC on hydrology. In this study, we allow the model to adapt land use related parameters to observed hydrological LUC effects by including the gradual nature of LUC in the calibration procedure. The SWAT model is an eco-hydrological model (here version SWAT2012, for documentation see Arnold et al., 2012; Gassman et al., 2007) which includes the possibility of gradual temporal changes on a daily basis (Pai and Saraswat, 2011). Only a few studies 
have implemented gradual land use change in their SWAT models (Chiang et al., 2010; George, 2014; Guse et al., 2015; Koch et al., 2012; Mani et al., 2014; Wagner et al., 2016). Even fewer have included an evaluation of the performance of the included gradual LUC in the calibration and validation period (Guse et al., 2015; Koch et al., 2012).

Aims and objective:

Therefore, we present here a study simulating the hydrological effects during the rapid historic LUC in the calibration and validation period for two contrasting macro-catchments: the das Mortes catchment with $17,556 \mathrm{~km}^{2}$ in the Cerrado biome $\left(-15.14^{\circ},-54.16^{\circ}\right)$ and the Jamanxim catchment with $37,403 \mathrm{~km}^{2}$ in the Amazon rainforest biome $\left(-7.34^{\circ},-55.84^{\circ}\right)$ including the gradual nature of LUC into the model setup. Furthermore, we assess in how far the inclusion of gradual LUC improves the model prediction by comparing the gradual LUC model setup to a setup with steady land use distribution. Lastly, the calibrated model for both catchments is put into practice for scenarios of future LUC with identical climate scenarios for the period 2026 to 2035 to estimate the magnitude of hydrological changes dependent on potential future LUC.

2. Study area and period:

The two catchments were chosen in areas of rapid historic deforestation and dominant rainfed agriculture to ensure that LUC effects are not influenced by technical water management (e.g. dams and irrigation). The das Mortes catchment is situated in the federal state of Mato Grosso. It is located on top of a plateau of cretaceous sandstone maintaining a large deep aquifer (Schneider, 1963). The climate is tropical wet and dry (dry period: May to September, Climate-Data.org, 2015), with an precipitation (P) of $1784 \mathrm{~mm} \mathrm{a}^{-1}$ (Primavera do Leste , Global Weather Data, 2015). The dominant soil types are the highly permeable Ferralsol (70\%) and Arenosol (23\%, see the Brazilian Agricultural Research Corporation (EMPRAPA) soil map profiles, ESALQ, 2015). The average slope is $2.9 \%$. Mato Grosso is the Brazilian state with the highest deforestation rate (Macedo et al., 2012). Deforestation rates are declining since 2000 (Davidson et al. 2012) due to exhaustion of forested areas on arable soils which are not protected in reservations. Parallel to the slowing deforestation in the last 15-20 years, land use in Mato Grosso and especially in the das Mortes catchment is characterised by intensification with a shift towards double cropping and minimum tillage (Beuchle et al., 2015; Galford et al., 2010; Hunke et al., 2015b). For the das Mortes catchment, the historic land use classification was relalised with Landsat satellite imagery analysis by Schlicht (2013) with an accuracy of $97 \%$ and an omission error of less than $1 \%$ (for 1988 and 1998). Deforestation for 1970 prior to be the first Landsat image was 1\% (IBGE, 2015). Consequently, the mid-1970s to mid-1980s are identified as the period with the most intensive deforestation in this area (Table 1). This coincides with the period 1968-1987 for which Guzha et al. (2013b) showed an increase in Q despite steady P records. For the das Mortes catchment, satellite and statistical information is not sufficient to reliably distinguish between cropland and pasture land uses. Consequently, the land use category "NonForest" was defined.

The Jamanxim catchment is located in the central southern part of the Amazon rainforest in the state of Pará. Its geological structure consists of Ordovician sedimentary and Precambrian metamorphic rocks (usouthal.edu, 2016). It has a tropical monsoon climate and a dry period from June to August (Climate-Data.org, 2015) with an annual P of 2232 mm (Novo Progresso, Global Weather Data, 2015). The dominant soil type is the deeply weathered Acrisol (84\%, see ZEE, 2015). The average slope is $12.7 \%$. The historic land use classification was realised with Landsat satellite imagery by Macioscheck (2013, for 1998, 2007 and 2011) with an accuracy of 99\% (Maciocheck, 2013). Deforestation rates peaked in the 2000s to open up pastures for cattle grazing. Compared to the total Brazilian Amazon 
Basin, pre 1990 deforestation in the Jamanxim catchment was comparatively low, increasing rapidly in the 1990s and 2000s, now reaching $15 \%$ (see Tabel 1 ).

For the das Mortes catchment, the period from 1977 to 1981 was chosen for calibration and 1982 to 1986 for validation. This period combines good $Q$ and $P$ records, the most rapid LUC and a change in the relationship of $Q$ and $P$. In the Jamanxim catchment the most rapid deforestation occurred in the last decade. Further, a longer time series of $Q$ is only available from 2000 to 2009 . Consequently, this period was chosen, with 2000 to 2004 for calibration and 2005 to 2009 for validation.

Furthermore, the scenario application in both catchments was set to the decade around the year 2030. Future LUC in the region is mainly dependent on political, economic and social development. The LANDSHIFT model (Schaldach et al., 2011; Schaldach and Koch, 2009) has the capability to estimate future LUC along storylines sketching political, economic and social development. For the two study regions, four different scenarios developed in an interdisciplinary effort by the Carbiocial project (carbiocial.de, Schönenberg et al., this issue) are taken into account: A trend scenario, where the development seen in the last decade will continue into the future, a sustainable scenario where regulations favour sectors with the most efficient land use, i.e. reduction of cattle ranching and a focus on crop production. Further, both the legal and illegal scenarios suggest a rapid agriculture expansion, either legal with the perpetuation of current protective areas or illegal without (for a detailed description refer to Göpel and Schaldach, this issue). The fractions of the land use in 2020, 2025 and 2030 of the four LANDSHIFT calculated scenarios are also listed in Table 1. The land use distribution in the das Mortes catchment does not ideally reflect the overall development associated with the scenarios. For example, the illegal scenario displays the highest fraction of scrubland vegetation (Cerrado). The trend scenario is marked with a $12-14 \%$ higher fraction of pasture. The highest fraction of cropland is associated with the sustainable scenario and continuously declines from legal to illegal to trend scenario. For the Jamanxim catchment, the scenario differences are as intended with the highest remaining forest cover and a complete elimination of pasture for the sustainable scenario. In 2030, the legal and illegal scenarios show a land use with $23 \%$ more forest clearance in 2030 compared to the sustainable scenario. However, they display different deforestation rates in the years before where the legal scenario behaves similar to the sustainable. Furthermore, deforestation is distributed differently over the catchment. The trend scenario has an intermediate fraction of forest removal and an intermediate extend of pasture.

\section{Setup and parametrisation of the SWAT2012 model}

a. Topography:

The SWAT model depends on a distributed representation of the catchment geometry and its river network (here, ASTER data sets (version 2) with $30 \mathrm{~m}$ grid cell resolution). It was delineated for the catchment outlet points at Toriquejé in the das Mortes catchment $\left(-15.25^{\circ},-53.06^{\circ}\right)$ and at Jardim do Ouro in the Jamanxim catchment $\left(-5.50^{\circ},-55.83^{\circ}\right)$. For the das Mortes catchment, sub-catchments are as best determined according to municipality borders to utilise information from the Brazilian Institute of Geography and Statistics (IBGE). In the Jamanxim catchment, sub-catchments include areas with similar land use.

b. Hydrological Response Unit (HRU) definition and management operations: For each sub-catchment HRUs with a unique soil, slope and land use are defined. SWAT allows the selective parametrisation of these smallest units of execution. The management in the das Mortes catchment includes double cropping (soy and corn) and cattle grazing for Non-Forest, depending on the soil type (good quality leads to cropping, poor quality to grazing). No management is 
implemented in Cerrado and gallery forest HRUs. For the Jamanxim catchment only HRUs with pasture are managed with cattle grazing.

\section{c. Vegetation parametrisation}

Parametrisation of new land use types were added to the SWAT2012 data base using a combination of literature data and own observations. Parameters for Cerrado and gallery forest were extracted from a range of eco-physiological and hydrological studies (Coe et al., 2009; Davidson et al., 2012; Lathuillière et al., 2012; Pongratz et al., 2006). For pasture, the SWAT 2012 database was extended with area specific information (Allen et al., 1998; Barona et al., 2010; Hayhoe et al., 2011; Lathuillière et al., 2012). Also, rainforest was added using literature information (Granier et al., 2000; Hayhoe et al., 2011; Kergoat, 1998; Sellers et al., 1989, 1996). A particular challenge is SWAT's dependency on the dormancy during the winter season for the reinitiation of the growing season for perennial plants. This process is not a valid growing pattern in the tropics. Therefore, the plant growth modification of Strauch and Volk (2013) - originally developed for the Cerrado biome - was applied for Cerrado, rainforest, gallery forest and pasture. Here, the start of the growing season is triggered by an increase of available soil water. Evapotranspiration and leaf area index (LAI) curves were adjusted by manually changing SWAT specific parameters determining the LAI curve shape to match observations (Christoffersen et al., 2014; Giambelluca et al., 2009; Lima et al., 1990; Oliveira, 2014; Oliveira et al., 2014; Strauch and Volk, 2013).

\section{d. Soil parametrisation}

With regard to soil surface parametrisation, surface runoff (Qsur) and infiltration are determined by the SCS Curve Number (CN) method (Mishra and Singh, 2003). The initial parameter estimates are taken from Drewry et al. (2008); Hunke et al. (2015b); McGrath et al. (2001) and Oliveira et al. (2014). Mean values for soil texture and bulk density were determined through statistical analysis of the RADAM soil profile data base (ESALQ, 2015; Jacomine, 2013). Lastly, hydraulic conductivity $\left(k_{\text {sat }}\right)$ for the main soil types was defined according to our own in situ measurements with a Compact Constant Head Permeameter (Amoozegar and Warrick, 1986).

e. Implementation of gradual land use change The LUC for the calibration, validation and each scenario application was calculated separately in each sub-catchment and updated on an annual basis. The land use distribution for years without information was estimated with linear interpolation, also for each sub-catchment separately. On average during the calibration and validation periods, every year $1.8 \%$ of Cerrado vegetation was converted into Non-Forest in the das Mortes catchment. In the Jamanxim catchment, $0.7 \%$ forest was transformed into pasture. The LUC is concentrated in the Western parts of the catchment, which is crossed by the BR 163. The sub-catchments crossed by the BR 163 have a deforestation rate of $2.4 \%$ p.a.. However, gradual LUC is connected to some shortcomings, since the SWAT land use update function allows only to redefine the fractions of existing HRUs, not the inclusion of new HRUs. In some cases it was not possible to redefine the land use class without also redefining either slope or soil class. In these cases areas of HRUs under LUC were preferable assigned to HRUs with the most similar soil type and slope class. Typically, for calibration, validation and scenario application this affected areas of less than $2.5 \%$. Only in the case of the calibration and validation period in the Rio das Mortes $6 \%$ of the catchment area had to be reassigned from the Latosolo Vermelho-Amarelo to the Latosolo Vermelho soil class. Since this are small areas and in the case of the soil reassignment similar soil types, we do not expect this to causes considerable changes to water balance calculation.

f. Weather data: 
The daily weather records from INMET and ANA (Instituto Nacional de Meteorologia, BDMEP 2015 and Agencia National de Aguas, ANA 2015) are applied in the das Mortes catchment. The P records are cross referenced for validity with CFSR reanalysed forecast data on a $35 \mathrm{~km}$ raster resolution (Fuka et al., 2014; Global Weather Data, 2015). For the das Mortes catchment, INMET and CFSR weather data are on average similar. In the Jamanxim catchment, due to the lack of weather data records, CFSR data is used as the source of weather information. Comparing the rainfall data with the closest weather station in Itaituba shows that the CFSR data is overestimating P in the wet season and underestimating $P$ in the dry season. The Itaituba INMET station records an annual average of $2070 \mathrm{~mm}$ ( $1530 \mathrm{~mm}$ in the rainy season and $540 \mathrm{~mm}$ in the dry season) for the period from 1961 to 2010 , whereas the mean of the CFSR data sets annual P to $2400 \mathrm{~mm}$ per annum ( $2105 \mathrm{~mm}$ in the rainy season and $295 \mathrm{~mm}$ in the dry season) for 1979 to 2014 . From this a P correction factor was calculated for each month of the year which adapts the CFSR data to the level measured at Itaituba. For all LUC scenarios, the IPPC SRES A1B climate scenario downscaled with the STAR method (Böhner et al., 2013; Böhner, this issue) for the period 2026 to 2035 is applied. The scenario predicts a considerable reduction in annual P of $29 \%$ in the das Mortes catchment and $32 \%$ in the Jamanxim catchment in comparison to the calibration and validation period.

g. Model calibration and validation:

The model calibration is based on the optimisation of the modelled monthly Q (Qmod) at the outlets of the catchments towards the observed values (Qobs). The daily Q information ("ANA" 2015, station 2650000 ) was transferred into monthly values. Both the calibration, and the estimation of the predictive uncertainty was automated with the software tool SWAT-CUP (Abbaspour, 2007) with the Sequential Uncertainty Fitting (SUFI-2) method (Abbaspour et al., 2004).

The calibration concentrates on two groups of calibration parameters: Firstly, parameters, which are generally sensitive, such as groundwater related parameters. These are adapted in the calibration procedure for the whole catchment. Secondly, parameters connected to land use, which are parameters defining vegetation growth and properties of the upper soil, such as $\mathrm{CN}$ and $\mathrm{k}_{\text {sat }}$. In the calibration procedure these were adapted for each soil and land use type combination separately. For all calibration parameters, physically meaningful ranges are defined as the parameter space. From these, random samples are taken with the latin hypercube method (Abbaspour, 2007) for each of the 1500 iterations for one calibration run.

At the end of the calibration run, the best estimation is identified with the Nash-Sutcliffe Efficiency index (NS) as the objective function. Further, the coefficient of determination $\left(R^{2}\right)$, percentual bias (PBIAS) and Root Mean Error (RME) are also calculated for the identified best estimation.

The uncertainty is calculated from the cumulative distribution of the output variable(s) $\left(i_{t}\right)$ for every output time step ( $t$, here monthly). The $95 \%$ confidence interval $(95 \mathrm{Cl})$ is the range between the $2.5 \%$ and $97.5 \%$ levels of the distribution of $i_{t}$, which relates to the reliability of the estimation procedure, not the probability of a value being estimated. Further, the $p$-factor (fractions of values within $95 \mathrm{Cl}$ ) and the $r$-factor (relative bandwidth of $\left.95 \mathrm{Cl}=\frac{95 \mathrm{CImax}-95 \mathrm{CImin}}{\left(i_{t} \text { mean }+i_{t} s d\right)-\left(i_{t} \text { mean-i } i_{t} s d\right)}\right)$ are evaluated. Each calibration run with 1500 iterations suggests a progressingly smaller calibration parameter range until the $95 \mathrm{Cl}$ of the model output is close to the standard deviation of the measured data. In order to generate comparable conditions for the calibration of the setup with and without gradual land use change, the initially identical parameter space was set to half its range in each consecutive calibration run. For each setup, calibration runs with 1500 iterations are repeated three times to achieve the before mentioned quality criterion. The final calibration parameter range from the setup with gradual land use change is then brought forward to be executed for the validation period (and the steady land use model setup from 1988 for the das Mortes catchment and from 2007 for the 
Jamanxim catchment). For the scenario application, only the optimum value for each calibration parameter defined through the setup including gradual land use change is implemented. In order to highlight the performance of the land use update setup, the predictive error ( $P E=Q$ obs-Qmod) of the catchment discharge is evaluated. Further, the LOcally WEigted Scatterplot Smoothing (LOWESS) as a nonparametric regression using multiple regression models (Cleveland, 1981) is applied to PE to visualise trends concealed by the variability of PE.

4. Results

a. Optimum values of selected calibration parameters:

A calibration parameter with fundamental influence especially on the distribution of water between the rainy and the dry season is the groundwater delay factor (given in days). This is a calibration parameter independent of land use, which determines the baseflow (Qgw) contribution to discharge. Since very little is known about the groundwater dynamics in both catchments, this parameter was defined during the calibration procedure. It displays a clear difference between the two study catchments. In the das Mortes catchment, Qgw makes up for $\sim 80 \%$ of $Q$, fed by an extensive groundwater buffer, represented by an optimum groundwater delay of 316 days, maintaining minimum $Q$ at $25 \%$ of the maximum $Q$. In the Jamanxim catchment, $Q$ generation is foremost influenced by interflow (Qint), causing $Q$ to be maintained at 5 to $10 \%$ of the maximum, which is associated with a much shorter groundwater delay of 74 days. This difference can be explained by the following characteristics of the catchments. The das Mortes catchment is dominated by a mostly flat relief (Guzha et al., 2013a) with sandy soils, causing water to percolate freely to the deep aquifer. Further, it is underlain by a pan like geological structure of cretaceous sandstone supporting an aquifer of up to $1300 \mathrm{~m}$ depth (Parana Mesozoic and Paleozonic groundwater province, Schneider, 1963). The Jamanxim catchment belongs to a greater part to the Central Precambrian groundwater province, which typically only supports a thin deep aquifer and wells with low yields (Schneider, 1963). Further, the relief is comparable steep supporting a faster lateral runoff.

There is strong evidence that LUC alters particularly the properties of the upper soil layer (Bruijnzeel, 2004; Christoffersen et al., 2014). Therefore, $C N$ and $k_{\text {sat }}$ of the upper most soil layer, which were initially parameterized according to soil type only, were adapted during the calibration procedure independent for each soil and land use type. Table 2 lists their land use dependent optimum values as suggested by the final iteration of the calibration runs with gradual land use change. Overall CN values are low, confirming the initial high infiltration into the upper soil layer in both catchments due to permeable soils. Nevertheless, the calibration procedure identified lower $\mathrm{CN}$ for natural vegetation compared to cropland and pasture. The calibration also suggests higher $k_{\text {sat }}$ values for natural vegetation compared to pasture and cropland in both catchments. Such a change of properties in the upper soil layer with LUC is in accordance with own measurements and literature data (Christoffersen et al., 2014; Hunke et al., 2015a).

b. Prediction quality:

The identified optimum calibration parameters result in a Qmod in good accordance with Qobs. Table 3 shows that if we are looking at NS both the das Mortes and the Jamanxim catchment have a very good to good performance rating for the calibration, validation of both land use update and steady land use application (Moriasi et al., 2007). The values are well within the results reported for other macro-catchment models (Fukunaga et al., 2015; Guzha et al., 2013a; Nandakumar and Mein, 1997; Schilling et al., 2008). Divergences between the land use update and steady land use application for the das Mortes catchment are reflected in NS and the r-factor. NS is considerable higher for the calibration with gradual land use. Further, the $r$-factors of both the calibration and validation period in the das Mortes catchment are smaller than in the steady land use application. 
Similar differences in the Jamanxim catchment are less pronounced, however perceivable. Here, the small fraction of areas with LUC (see Table 1) compared to the large area of remaining rainforest buffers the responses of the hydrological balance.

To highlight the different performance of the land use update and the steady land use setup, Figure $2 a$ shows the $P E$ between Qobs and model Qmod for land use update $\left(P E_{1}\right)$ and steady land use $\left(P E_{2}\right)$ setup in the das Mortes catchment. PE shows that both overprediction (negative PE) and underprediction (positive $\mathrm{PE}$ ) are more pronounced for a steady land use setup $\left(\mathrm{PE}_{2}\right)$. LOWESS regressions are applied to show the trend in PE over the application period. Both PEs decline towards the end of the period. Additionally, the difference between $\mathrm{PE}_{1}$ and $\mathrm{PE}_{2}$ declines, showing that the steady land use setup prediction becomes more accurate towards the date of the applied land use distribution (from the year 1988). Similar, but less pronounced differences can be seen in the PEs for the Jamanxim catchment in Figure $2 \mathrm{~b}$. Again, the steady land use setup has both a higher over- and underprediction of the observed discharge. If looking at the LOWESS regression, in the first seven years of the application period, the land use update setup shows a slightly lower underprediction compared to the steady setup. For the year 2007, the land use update $\mathrm{PE}_{1}$ and the steady land use $\mathrm{PE}_{2}$ are the same.

\section{c. Scenario application}

The four LUC scenario applications in each catchment (for degree of LUC refer to Table 1 ) were executed with identical climate projections to reflect purely on alteration of WBCs due to LUC. Mean annual WBCs in relation to mean annual P for the scenario period from 2026 to 2035 are shown in Figure $3 a$ and $b$. In the das Mortes catchment, the WBC in the sustainable, legal and illegal scenarios are of the same magnitude reflecting the distribution of land cover with only a gradual change of Cerrado and cropland. Only the trend scenario with the highest fraction of pasture results in a higher $Q$ due to a lower evapotranspiration and $\mathrm{k}_{\text {sat }}$ reduction. Moreover, it is the scenario with the highest surface runoff, however rates are generally limited to less than $1 \mathrm{~mm} \mathrm{month}{ }^{-1}$. Considerable surface runoff ( $>10 \mathrm{~mm} \mathrm{month}^{-1}$ ) only occurs in the Western parts of the catchment (on Latosolo) during the very wet month of February in 2034 with more than $400 \mathrm{~mm}$ P causing soil saturation and therefore soil saturation excess runoff.

The land cover scenarios in the Jamanxim catchment show gradual differences between all scenarios. Differences in $Q$ are mirrored in ET with the lowest $Q$ and highest ET for the sustainable scenario with forest protection and an elimination of pastures. Surface runoff is limited to the steep headwater catchments in the south.

Additionally to the changes in the overall WBC, the seasonality of runoff generation changes. Figure 4 shows monthly $\triangle Q$ for the sustainable, legal and illegal scenario, where $\Delta Q$ is the difference between $\mathrm{Q}$ of the trend scenario and $\mathrm{Q}$ of each of the other scenarios $\left(\Delta \mathrm{Q}=\mathrm{Q}_{\text {trend scenario- }} \mathrm{Q}_{\text {other scenraios }}\right)$. For the seasonal comparison, the trend scenario $Q$ is also plotted. The differences in mean $Q$ are not distributed equally throughout the year but predominantly associated with the peak discharge months. In the das Mortes catchment, highest $\Delta Q$ is found during rising $Q$ at the beginning of the rainy season. Additionally, during the low flow period in dry years, the trend scenario maintains higher flows. The trend scenario has the highest proportion of pasture, which means that pasture generates more runoff at the beginning of the rainy season and higher Qgw compared to the other land use types. This is in accordance with research showing that pasture causes higher peak discharge (Costa et al., 2003; Drewry et al., 2008; Guzha et al., 2013b; Hodnett et al., 1995; Hunke et al., 2015a). We account this to the ready available leaf area resulting in immediate evapotranspiration (Cerrado) of the received $\mathrm{P}$ and a higher water storage capacity of the less compacted soil. 
In the Jamanxim catchment, largest $\Delta Q$ s are associated with the sustainable scenarios, with the highest fraction of remaining forest cover. The trend scenario has a land cover distribution similar to the legal and illegal scenario and therefore $\Delta \mathrm{Q}$ s are very low. The pattern of $\Delta \mathrm{Q}$ for the sustainable scenario follows a pattern of lower discharge, especially during the rising stage of the wet season and the maintenance of higher flows during the dry season.

This seasonal pattern is potentially characteristic for hydrological effects of LUC in areas with pronounced wet and dry periods, since it was also observed in a similar SWAT model application including gradual LUC by Wagner et al. (2016) for a catchment in India with monsoon climate.

\section{Discussion:}

For our catchments with intensive LUC in the calibration and validation period, the model setups including gradual land use change show a better performance than the model setups with a steady land use distribution. This is reflected in the throughout smaller PE of the land use update setup in the two contrasting catchments. The difference between the error calculations of the two setups is dependent on the degree of LUC. In the das Mortes catchment with $1.8 \%$ deforestation per annum, absolute $\mathrm{PE}_{1}$ is on average $19 \mathrm{~mm}$ per annum smaller (corresponding to $11.2 \% \mathrm{Q}$ or $1.8 \% \mathrm{P}$ ) than absolute $\mathrm{PE}_{2}$. For the Jamanxim catchment with $0.7 \%$ deforestation per annum, the difference is 8 $\mathrm{mm}$ per annum (corresponding to $1.2 \% \mathrm{Q}$ or $0.4 \% \mathrm{P}$ ).

Classically, land use influence on water balance is dependent on differences in evapotranspiration. Here we also included the differentiation of properties of the upper soil layer under different land use. For each land use and soil type combination, these are adapted independently in the calibration procedure. The calibration results support that LUC is accompanied by soil compaction processes through deforestation and agricultural land use. Remarkably, our results fit well with reported field research findings, regarding the soil compaction through land use in this area (Bruijnzeel, 2004; Christoffersen et al., 2014; Drewry et al., 2008; Hunke et al., 2015b; Nobrega et al., 2015; Scheffler et al., 2011). These established higher optimum $C N$ and lower optimum $k_{\text {sat }}$ values for cropland and pasture compared to natural vegetation have a clear effect on $Q$ prediction. This agreement of field records and calibration outputs indicates an adequate representation of pedo-hydrological processes connected to LUC.

The model applications are an advanced tool to contribute to the discussion about changes of WBC due to future LUC, since they include both, the change of evapotranspiration and soil properties with LUC. Moreover, in many cases LUC effects on hydrology are subordinate to CC effect. Therefore, the different LUC scenarios are simulated with the same climate scenario to ensure that all observed hydrological effects are purely LUC effects. According to our results, for both the das Mortes and the Jamanxim catchment, the model shows an increase of $Q$ with continuous deforestation. For the das Mortes catchment, a reduction of Cerrado of $5 \%$ and an increase of pasture of $12 \%$ (compare illegal to trend scenario 2030) results in an $3.4 \%$ increase of annual $Q$, which confirms findings of (Costa et al., 2003; Guzha et al., 2013a). In the Jamanxim catchment, 24\% more deforestation (compare sustainable to illegal scenario 2030) increases $Q$ by $13 \mathrm{~mm}$ per annum $(2.0 \%$ of $Q, 0.8 \%$ of the $P$ ). However, Coe et al. (2009) and Lima et al. (2013) stress the fact, that $P$ is dependent on recycled transpiration from the forest vegetation (P-feedback). This process is most effective in the rainforest biome, where studies state that with complete deforestation, $\mathrm{P}$ is reduced by 20 to $35 \%$ (D'Almeida et al., 2007; De Paiva et al., 2013; Nobre et al., 1991). Coe et al. (2009) and Lima et al. (2013) both showed with the application of a model with and without P-feedback, that the inclusion of Pfeedback is crucial for $Q$ prediction in the Amazon rainforest biome. Our Jamanxim results are similar to the results of the Coe et al., (2009) model without P-feedback, where a deforestation of $26 \%$ leads 
to an $8 \%$ increase of $Q$, however, with $P$-feedback for the same area Coe et al. (2009) find $Q$ to decrease by $12 \%$. Consequently, for our model a more accurate prediction needs to include Pfeedback. This cannot be realised in SWAT directly, but needs to be incooperated in the climate model. In the current STAR climate prediction an adaption of $\mathrm{P}$ according to the different LUC scenarios is not implemented, not least because of the complex nature of P-feedback, which is highly dependent on deforestation pattern (Negri et al., 2004). However, our future research aims to include these complex feedbacks.

Independent of P-feedback effects, a comparison of scenarios suggests a severe influence of conversion into pasture on the WBC. In the das Mortes catchment, a 13\% increase of pasture (compare trend and sustainable scenario) causes a 4 to $27 \mathrm{~mm}$ (13.3-73.0\%) increase in monthly $Q$ at the beginning of the rainy season (December and January) due to decreased evapotranspiration and an increase in Qsur and interflow (Qint, Fig. 4a). The differences in Q seasonality for increased Q due to pasture and cropland area are similar in the Jamanxim catchment. For example, $14 \%$ more cropland (compare trend and legal scenario in 2030) leads to up to $30 \mathrm{~mm} \mathrm{month}^{-1}$ higher discharge during the rainy season.

Conclusions:

- Through the implementation of gradual land use change, the accordance of Qmod and Qobs is improved by $11.2 \%$ in the catchment with $1.8 \%$ annual deforestation and by $1.2 \%$ in the catchment with $0.7 \%$ annual deforestation. This demonstrates that in regions with intensive LUC during the application of a hydrological model, the inclusion of gradual land use change is necessary to ensure the best possible prediction quality.

- The model predictions for four land use scenarios in two fundamentally different macrocatchments show changes in WBC predominantly during the wet season, with strongest effects for the conversion of native vegetation (Cerrado and rainforest) to pasture.

- In the das Mortes catchment with the more pronounced dry season, the ground water components are more relevant for annual discharge generation. The more seasonal climate also coincides with more pronounced LUC effects on hydrology at the beginning of the rainy season, whereas under less seasonal rainforest climate ( $\leq 3$ arid month), LUC effects on hydrology are apparent during the whole rainy season.

Acknowledgements:

This study was carried out in the framework of the integrated project CarBioCial funded by the German Ministry of Education and Research (BMBF) under the grant number 01LL0902F. 
440 Abbaspour KC. 2007. User manual for SWAT-CUP, SWAT calibration and uncertainty analysis 441 programs. Swiss Federal Institute of Aquatic Science and Technology, Eawag, Duebendorf, 442 Switzerland.

443 Abbaspour KC, Johnson CA, van Genuchten MT. 2004. Estimating uncertain flow and transport parameters using a sequential uncertainty fitting procedure. Vadose Zone Journal 3(4): 1340. DOI:

445 10.2136/vzj2004.1340.

Allen RG, Pereira LS, Raes D, Smith M, others. 1998. Crop evapotranspiration-Guidelines for computing crop water requirements-FAO Irrigation and drainage paper 56. FAO, Rome 300(9).

Amoozegar A, Warrick AW. 1986. Hydraulic Conductivity of Saturated Soils: Field Methods. Methods of Soil Analysis: Part 1-Physical and Mineralogical Methods 735-770. DOI: 10.2136/sssabookser5.1.2ed.c29.

Arima EY, Richards P, Walker R, Caldas MM. 2011. Statistical confirmation of indirect land use change in the Brazilian Amazon. Environmental Research Letters 6(2): 24010. DOI: 10.1088/17489326/6/2/024010.

Arnold JG, Moriasi DN, Gassman PW, Abbaspour KC, White MJ, Srinivasan R, Santhi C, Harmel RD, Van Griensven A, Van Liew MW, others. 2012. SWAT: Model use, calibration, and validation. Transactions of the ASABE 55(4): 1491-1508.

Barona E, Ramankutty N, Hyman G, Coomes OT. 2010. The role of pasture and soybean in deforestation of the Brazilian Amazon. Environmental Research Letters 5(2): 24002.

Beuchle R, Grecchi RC, Shimabukuro YE, Seliger R, Eva HD, Sano E, Achard F. 2015. Land cover changes in the Brazilian Cerrado and Caatinga biomes from 1990 to 2010 based on a systematic remote sensing sampling approach. Applied Geography 58: 116-127. DOI: 10.1016/j.apgeog.2015.01.017.

Beven K. 2010. Environmental modelling: an uncertain future? CRC Press: Routledge.

Böhner J. this issue. Paradigm in modelling climate change - results with STAR and WRF. .

Böhner J, Dietrich H, Fraedrich K, Kawohl T, Kilian M, Lucarini V, Lunkeit F. 2013. Development and implementation of a hierarchical model chain for modelling regional climate variability and climate change over southern Amazonia. Interdisciplinary Analysis and Modeling of Carbon-Optimized Land Management Strategies for Southern Amazonia, Universitätsdrucke Göttingen 119-128.

Bozana Maciocheck. 2013. Change Detection im Wassereinzugsgebiet Novo Progresso (Pará, Brasilien). Göttingen, Germany.

Bronstert A, Niehoff D, Bürger G. 2002. Effects of climate and land-use change on storm runoff generation: present knowledge and modelling capabilities. Hydrological Processes 16(2): 509-529. DOI: 10.1002/hyp.326.

Bruijnzeel LA. 2004. Hydrological functions of tropical forests: not seeing the soil for the trees? Agriculture, Ecosystems \& Environment 104(1): 185-228. DOI: 10.1016/j.agee.2004.01.015. 
Chiang L, Chaubey I, Gitau MW, Arnold JG. 2010. Differentiating impacts of land use changes from pasture management in a CEAP watershed using the SWAT model. Trans. ASABE 53(5): 1569-1584.

Christoffersen BO, Restrepo-Coupe N, Arain MA, Baker IT, Cestaro BP, Ciais P, Fisher JB, Galbraith D, Guan X, Gulden L, others. 2014. Mechanisms of water supply and vegetation demand govern the seasonality and magnitude of evapotranspiration in Amazonia and Cerrado. Agricultural and Forest meteorology 191: 33-50. DOI: 10.1016/j.agrformet.2014.02.008.

Cleveland WS. 1981. LOWESS: A program for smoothing scatterplots by robust locally weighted regression. American Statistician 54-54. DOI: 10.2307/2683591.

Climate-Data.org. 2015. Climate data for cities worldwide. http://en.climate-data.org/, Accessed 27 May 2015.

Coe MT, Costa MH, Soares-Filho BS. 2009. The influence of historical and potential future deforestation on the stream flow of the Amazon River - Land surface processes and atmospheric feedbacks. Journal of Hydrology 369(1-2): 165-174. DOI: 10.1016/j.jhydrol.2009.02.043.

Costa MH, Botta A, Cardille JA. 2003. Effects of large-scale changes in land cover on the discharge of the Tocantins River, Southeastern Amazonia. Journal of Hydrology 283(1-4): 206-217. DOI: 10.1016/S0022-1694(03)00267-1.

D’Almeida C, Vörösmarty CJ, Hurtt GC, Marengo JA, Dingman SL, Keim BD. 2007. The effects of deforestation on the hydrological cycle in Amazonia: a review on scale and resolution. International Journal of Climatology 27(5): 633-647. DOI: 10.1002/joc.1475.

Davidson EA, de Araújo AC, Artaxo P, Balch JK, Brown IF, C. Bustamante MM, Coe MT, DeFries RS, Keller M, Longo M, Munger JW, Schroeder W, Soares-Filho BS, Souza CM, Wofsy SC. 2012. The Amazon basin in transition. Nature 481(7381): 321-328. DOI: 10.1038/nature10717.

De Paiva RCD, Buarque DC, Collischonn W, Bonnet M-P, Frappart F, Calmant S, Bulhões Mendes CA. 2013. Large-scale hydrologic and hydrodynamic modeling of the Amazon River basin. Water Resources Research 49(3): 1226-1243. DOI: 10.1002/wrcr.20067.

De Roo A, Odijk M, Schmuck G, Koster E, Lucieer A. 2001. Assessing the effects of land use changes on floods in the Meuse and Oder catchment. Physics and Chemistry of the Earth, Part B: Hydrology, Oceans and Atmosphere 26(7): 593-599.

DeFries R, Eshleman KN. 2004. Land-use change and hydrologic processes: a major focus for the future. Hydrological Processes 18(11): 2183-2186. DOI: 10.1002/hyp.5584.

Drewry JJ, Cameron KC, Buchan GD. 2008. Pasture yield and soil physical property responses to soil compaction from treading and grazing - a review. Soil Research 46(3): 237-256. DOI: 10.1071/SR07125.

ESALQ. 2015. Escola Superior de Agricultura "Luiz de Queiroz." http://www.esalq.usp.br/gerd/ Accessed 1 June 2015.

Fearnside PM. 2005. Deforestation in Brazilian Amazonia: history, rates, and consequences. Conservation biology 19(3): 680-688. DOI: 10.1111/j.1523-1739.2005.00697.x.

Fearnside PM. 2007. Brazil's Cuiabá-Santarém (BR-163) Highway: the environmental cost of paving a soybean corridor through the Amazon. Environmental management 39(5): 601-614. 
Fuka DR, Walter MT, MacAlister C, Degaetano AT, Steenhuis TS, Easton ZM. 2014. Using the Climate Forecast System Reanalysis as weather input data for watershed models. Hydrological Processes 28(22): 5613-5623. DOI: 10.1002/hyp.10073.

Fukunaga DC, Cecílio RA, Zanetti SS, Oliveira LT, Caiado MAC. 2015. Application of the SWAT hydrologic model to a tropical watershed at Brazil. CATENA 125: 206-213. DOI: 10.1016/j.catena.2014.10.032.

Galford GL, Melillo J, Mustard JF, Cerri CEP, Cerri CC. 2010. The Amazon Frontier of Land-Use Change: Croplands and Consequences for Greenhouse Gas Emissions. Earth Interactions 14(15): 1-24. DOI: 10.1175/2010EI327.1.

Gassman PW, Reyes MR, Green CH, Arnold JG. 2007. Soil and Water Assessment Tool: Historical Development, Applications, and Future Research Directions, The. Center for Agricultural and Rural Development lowa State University Working Paper 07-WP 443.

George C. 2014. Simulation of Hydrologic Impacts of Land Use Land Cover Changes in a Humid Tropical River Basin. .

Giambelluca TW, Scholz FG, Bucci SJ, Meinzer FC, Goldstein G, Hoffmann WA, Franco AC, Buchert MP. 2009. Evapotranspiration and energy balance of Brazilian savannas with contrasting tree density. Agricultural and Forest Meteorology 149(8): 1365-1376. DOI: 10.1016/j.agrformet.2009.03.006.

Global Weather Data. 2015. http://globalweather.tamu.edu/Accessed 31 May 2015.

Göpel J, Schaldach R. this issue. Sustainable land management in Southern Amazonia: Model-based analysis of the robustness of carbon-optimized management systems under global change pressures.

Granier A, Loustau D, Bréda N. 2000. A generic model of forest canopy conductance dependent on climate, soil water availability and leaf area index. Annals of Forest Science 57(8): 11. DOI: 10.1051/forest:2000158.

Guse B, Pfannerstill M, Fohrer N. 2015. Dynamic modelling of land use change impacts on nitrate loads in rivers. Environmental Processes 2(4): 575-592.

Guzha A, Nobrega R, Kovacs K, Amorim RSS, Gerold G. 2013a. Quantifying impacts of agro-industrial expansion in Mato Grosso, Brazil, on watershed hydrology using the Soil and Water Assessment Tool (SWAT) model. paper presented at the Conference: 20th International Congress on Modelling and Simulation. Adelaide, Australia. DOI: 10.5194/hessd-12-9915-2015.

Guzha A, Nobrega R, Santos C, Gerold G. 2013b. Investigating discharge and rainfall variability in an Amazonian watershed: Do any trends exist? IAHS-AISH publication 346-351.

Hayhoe SJ, Neill C, Porder S, Mchorney R, Lefebvre P, Coe MT, Elsenbeer H, Krusche AV. 2011. Conversion to soy on the Amazonian agricultural frontier increases streamflow without affecting stormflow dynamics. Global Change Biology 17(5): 1821-1833. DOI: 10.1111/j.13652486.2011.02392.x.

Hodnett MG, da Silva LP, da Rocha HR, Cruz Senna R. 1995. Seasonal soil water storage changes beneath central Amazonian rainforest and pasture. Journal of Hydrology 170(1-4): 233-254. DOI: 10.1016/0022-1694(94)02672-X. 
Hunke P, Mueller EN, Schröder B, Zeilhofer P. 2015a. The Brazilian Cerrado: assessment of water and soil degradation in catchments under intensive agricultural use. Ecohydrology 8(6): 1154-1180. DOI: 10.1002/eco.1573.

Hunke P, Roller R, Zeilhofer P, Schröder B, Mueller EN. 2015b. Soil changes under different land-uses in the Cerrado of Mato Grosso, Brazil. Geoderma Regional 4: 31-43. DOI: 10.1016/j.geodrs.2014.12.001.

Jacomine PKT. 2013. A nova classificacao brasileira de solos. Anais da Academia Pernambucana de Ciência Agronômica 5(0): 161-179.

Kergoat L. 1998. A model for hydrological equilibrium of leaf area index on a global scale. Journal of Hydrology 212-213: 268-286. DOI: 10.1016/S0022-1694(98)00211-X.

Koch FJ, van Griensven A, Uhlenbrook S, Tekleab S, Teferi E. 2012. The Effects of Land use Change on Hydrological Responses in the Choke Mountain Range (Ethiopia)-A new Approach Addressing Land Use Dynamics in the Model SWAT. Proceedings of 2012 International Congress on Environmental Modeling and Software Managing Resources of a Limited Planet, Sixth Biennial Meeting, Leipzig, Germany, 1-5.

Lambin EF, Turner BL, Geist HJ, Agbola SB, Angelsen A, Bruce JW, Coomes OT, Dirzo R, Fischer G, Folke C, George PS, Homewood K, Imbernon J, Leemans R, Li X, Moran EF, Mortimore M, Ramakrishnan PS, Richards JF, Skånes H, Steffen W, Stone GD, Svedin U, Veldkamp TA, Vogel C, Xu J. 2001. The causes of land-use and land-cover change: moving beyond the myths. Global Environmental Change 11(4): 261-269. DOI: 10.1016/S0959-3780(01)00007-3.

Lathuillière MJ, Johnson MS, Donner SD. 2012. Water use by terrestrial ecosystems: temporal variability in rainforest and agricultural contributions to evapotranspiration in Mato Grosso, Brazil. Environmental Research Letters 7(2): 24024. DOI: 10.1088/1748-9326/7/2/024024.

Lima LS, Coe MT, Filho BSS, Cuadra SV, Dias LCP, Costa MH, Lima LS, Rodrigues HO. 2013. Feedbacks between deforestation, climate, and hydrology in the Southwestern Amazon: implications for the provision of ecosystem services. Landscape Ecology 29(2): 261-274. DOI: 10.1007/s10980-013-99621.

Lima W de P, Zakia MB, Libardi PL, de Souza Filho AP, others. 1990. Comparative evapotranspiration of eucalyptus, pine and natural "cerrado" vegetation measure by the soil water balance method". Ipef International, Piracicaba.

Macedo MN, DeFries RS, Morton DC, Stickler CM, Galford GL, Shimabukuro YE. 2012. Decoupling of deforestation and soy production in the southern Amazon during the late 2000s. Proceedings of the National Academy of Sciences 109(4): 1341-1346. DOI: 10.1073/pnas.1111374109.

Macioscheck B. 2013. Land use classification upper Jamanxim catchment. ESRI ArcGIS shape files. Göttingen, Germany.

Maia SMF, Ogle SM, Cerri CEP, Cerri CC. 2010. Soil organic carbon stock change due to land use activity along the agricultural frontier of the southwestern Amazon, Brazil, between 1970 and 2002. Global Change Biology 16(10): 2775-2788. DOI: 10.1111/j.1365-2486.2009.02105.x.

Mani A, Devi MU, Ramulu V, others. 2014. Simulation of Impact of Change in Landuse on Water Yield of Upper Manair Catchment. International Journal of Innovative Research and Development 3(1). 
McGrath DA, Smith CK, Gholz HL, Oliveira F de A. 2001. Effects of Land-Use Change on Soil Nutrient Dynamics in Amazônia. Ecosystems 4(7): 625-645. DOI: 10.1007/s10021-001-0033-0.

Miles L, Newton AC, DeFries RS, Ravilious C, May I, Blyth S, Kapos V, Gordon JE. 2006. A global overview of the conservation status of tropical dry forests. Journal of Biogeography 33(3): 491-505. DOI: $10.1111 /$ j.1365-2699.2005.01424.x.

Mishra SK, Singh VP. 2003. Soil Conservation Service Curve Number (SCS-CN) Methodology. Springer Science \& Business Media.

Moriasi DN, Arnold JG, Van Liew MW, Bingner RL, Harmel RD, Veith TL. 2007. Model evaluation guidelines for systematic quantification of accuracy in watershed simulations. Trans. Asabe 50(3): 885-900.

Müller H, Rufin P, Griffiths P, Barros Siqueira AJ, Hostert P. 2015. Mining dense Landsat time series for separating cropland and pasture in a heterogeneous Brazilian savanna landscape. Remote Sensing of Environment 156: 490-499. DOI: 10.1016/j.rse.2014.10.014.

Nandakumar N, Mein RG. 1997. Uncertainty in rainfall-runoff model simulations and the implications for predicting the hydrologic effects of land-use change. Journal of Hydrology 192(1-4): 211-232. DOI: 10.1016/S0022-1694(96)03106-X.

Negri AJ, Adler RF, Xu L, Surratt J. 2004. The impact of Amazonian deforestation on dry season rainfall. Journal of Climate 17(6): 1306-1319.

Nobre CA, Sellers PJ, Shukla J. 1991. Amazonian Deforestation and Regional Climate Change. Journal of Climate 4(10): 957-988. DOI: 10.1175/1520-0442(1991)004<0957:ADARCC>2.0.CO;2.

Nobrega RLB, A. C. Guzha, G. N. Torres, K. Kovacs, G. Lamparter, R. S. S. Amorim, E. Couto, G. Gerold. 2015. Identifying hydrological responses of micro-catchments under contrasting land use in the Brazilian Cerrado. Hydrology and Earth System Sciences 19. DOI: 10.5194/hessd-12-9915-2015.

Oliveira PS. 2014. Balanço hídrico e erosão do solo no Cerrado Brasileiro. Sao Paulo, School of engineering, department of hydraulics and sanitary engineering.

Oliveira PTS, Nearing MA, Moran MS, Goodrich DC, Wendland E, Gupta HV. 2014. Trends in water balance components across the Brazilian Cerrado. Water Resources Research 50(9): 7100-7114. DOI: 10.1002/2013WR015202.

Pai N, Saraswat D. 2011. SWAT 2009 _LUC: A Tool to Activate the Land Use Change Module in SWAT 2009. Transactions of the ASABE 54(5): 1649-1658.

Pongratz J, Bounoua L, DeFries RS, Morton DC, Anderson LO, Mauser W, Klink CA. 2006. The Impact of Land Cover Change on Surface Energy and Water Balance in Mato Grosso, Brazil. Earth Interactions 10(19): 1-17. DOI: 10.1175/EI176.1.

Price K. 2011. Effects of watershed topography, soils, land use, and climate on baseflow hydrology in humid regions: A review. Progress in physical geography 35(4): 465-492.

Rodrigues ASL, Ewers RM, Parry L, Souza C, Veríssimo A, Balmford A. 2009. Boom-and-Bust Development Patterns Across the Amazon Deforestation Frontier. Science 324(5933): 1435-1437. DOI: $10.1126 /$ science.1174002. 
Schaldach R, Alcamo J, Koch J, Kölking C, Lapola DM, Schüngel J, Priess JA. 2011. An integrated approach to modelling land-use change on continental and global scales. Environmental Modelling \& Software 26(8): 1041-1051. DOI: 10.1016/j.envsoft.2011.02.013.

Schaldach R, Koch J. 2009. Conceptual design and implementation of a model for the integrated simulation of large-scale land-use systems. In: Athanasiadis DIN, Rizzoli PAE, Mitkas PA and Gómez PD-IJM (eds) Information Technologies in Environmental Engineering. Springer Berlin Heidelberg, 425-438, DOI:10.1007/978-3-540-88351-7_32.

Scheffler R, Neill C, Krusche AV, Elsenbeer H. 2011. Soil hydraulic response to land-use change associated with the recent soybean expansion at the Amazon agricultural frontier. Agriculture, Ecosystems \& Environment 144(1): 281-289. DOI: 10.1016/j.agee.2011.08.016.

Schilling KE, Jha MK, Zhang Y-K, Gassman PW, Wolter CF. 2008. Impact of land use and land cover change on the water balance of a large agricultural watershed: Historical effects and future directions. Water Resources Research 44(7): W00A09. DOI: 10.1029/2007WR006644.

Schlicht S. 2013. Dynamics of deforestation and agricultural production in the upper Rio das Mortes watershed in Mato Grosso state (Brazil). M.Sc thesis, Göttingen, Germany, University of Göttingen.

Schneider R. 1963. Groundwater Proviceces Brazil. Preared in coopertaion with the Government of Brazil and the United Staes Operation Mission to Brazil. Washington, USA.

Schönenberg R, Hartberger, Korbinian, Schumann, Charlotte, Guggenberger, Georg, Siebold, Mathias, Boy, Jens, Lakes, Lamparter, Gabriele, Schindewolf, Marcus, Nendel, Claas, Hohnwald, Stefan, Gerold, Gerhard, Klingler, Michael. this issue. Methods of inter- and transdisciplinary research - a trajectory of knowledge integration. .

Sellers PJ, Randall D a., Collatz G j., Berry J a., Field C b., Dazlich D a., Zhang C, Collelo G d., Bounoua L. 1996. A Revised Land Surface Parameterization (SiB2) for Atmospheric GCMS. Part I: Model Formulation. Journal of Climate 9(4): 676-705. DOI: 10.1175/15200442(1996)009<0676:ARLSPF>2.0.CO;2.

Sellers PJ, Shuttleworth WJ, Dorman JL, Dalcher A, Roberts JM. 1989. Calibrating the Simple Biosphere Model for Amazonian Tropical Forest Using Field and Remote Sensing Data. Part I: Average Calibration with Field Data. Journal of Applied Meteorology 28(8): 727-759. DOI: 10.1175/15200450(1989)028<0727:CTSBMF>2.0.CO;2.

Strauch M, Volk M. 2013. SWAT plant growth modification for improved modeling of perennial vegetation in the tropics. Ecological Modelling 269: 98-112. DOI: 10.1016/j.ecolmodel.2013.08.013.

usouthal.edu. 2016. Brzilian Geological Map. .

Wagner PD, Bhallamudi SM, Narasimhan B, Kantakumar LN, Sudheer KP, Kumar S, Schneider K, Fiener P. 2016. Dynamic integration of land use changes in a hydrologic assessment of a rapidly developing Indian catchment. Science of The Total Environment 539: 153-164. DOI: 10.1016/j.scitotenv.2015.08.148.

Wertz-Kanounnikoff SA. 2005. Forest policy enforcement at the Amazon frontier : the case of Mato Grosso, Brazil. Dissertation.

ZEE ZEE. 2015. , http://www.zee.mg.gov.br/. http://www.zee.mg.gov.br/Accessed 31 May 2015. 
671

672 


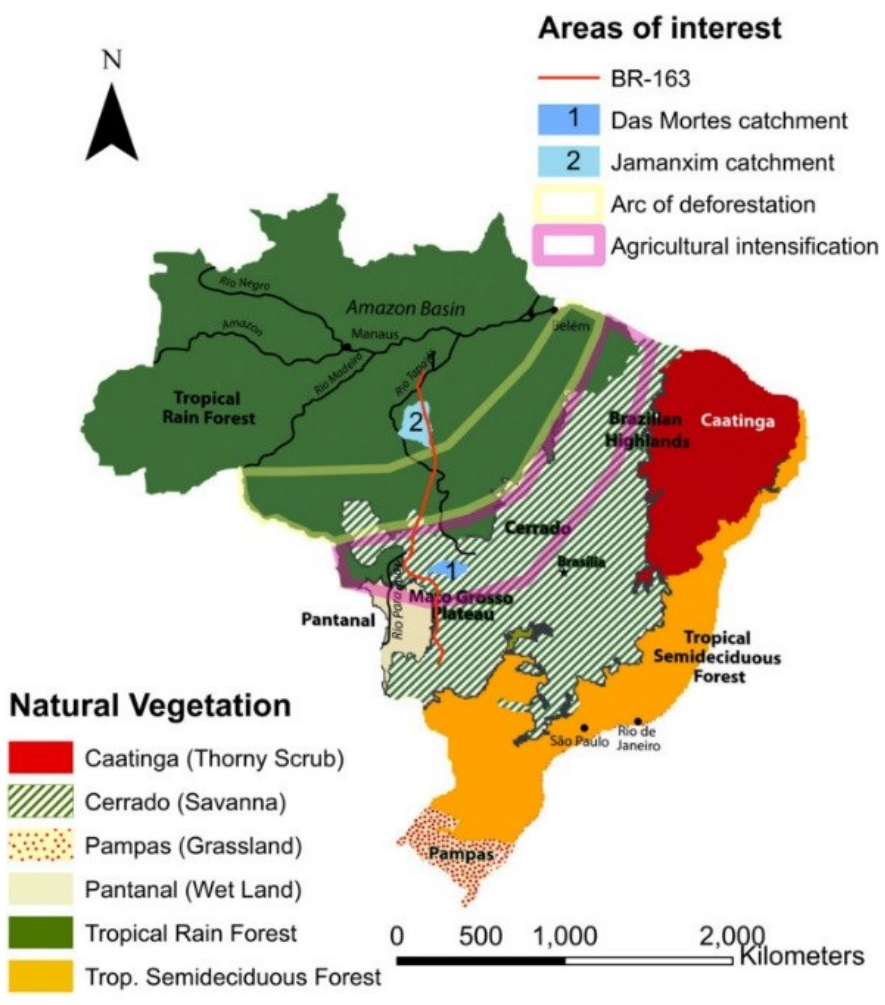

Figure :1 Vegetation biomes in Brazil, locations of the study catchments, the BR-163 and the current extent of the Amazon agricultural frontier (base map from "Forests in Brazil" 2015; frontier

676 reproduced after "Global Forest Watch" 2015)

677 Table 1: Main land use types during the historic calibration and validation period (Landsat imagery 678 evaluation and *statistical data) and for future LUC scenarios (developed with LANDSHIFT (Göpel and 679 Schaldach, this issue)

\begin{tabular}{|l|l|l|l|l|l|l|}
\hline & \multicolumn{3}{|l}{ Das Mortes catchment } & \multicolumn{3}{l|}{ Jamanxim catchment } \\
\hline Historic & $\mathbf{1 9 7 0}$ & $\mathbf{1 9 8 8}$ & $\mathbf{1 9 9 8}$ & $\mathbf{1 9 9 8}$ & $\mathbf{2 0 0 7}$ & $\mathbf{2 0 1 1}$ \\
\hline Cerrado and Forest & $97 . \mathbf{F}^{*}$ & 64.26 & 39.79 & 95.34 & 91.42 & 85.03 \\
\hline Cropland & - & - & - & 0.10 & 0.03 & 0.09 \\
\hline Non-Forest/Pasture & $2.00^{*}$ & 35.57 & 59.89 & 4.34 & 8.34 & 14.57 \\
\hline Trend Scenario & $\mathbf{2 0 2 0}$ & $\mathbf{2 0 2 5}$ & $\mathbf{2 0 3 0}$ & $\mathbf{2 0 2 0}$ & $\mathbf{2 0 2 5}$ & $\mathbf{2 0 3 0}$ \\
\hline Cerrado and Forest & 12.53 & 11.42 & 10.96 & 83.31 & 79.59 & 77.20 \\
\hline Cropland & 54.31 & 54.31 & 54.31 & 9.91 & 10.06 & 10.09 \\
\hline Pasture & 32.93 & 34.04 & 34.50 & 5.42 & 9.17 & 11.61 \\
\hline Sustainable Scenario & $\mathbf{2 0 2 0}$ & $\mathbf{2 0 2 5}$ & $\mathbf{2 0 3 0}$ & $\mathbf{2 0 2 0}$ & $\mathbf{2 0 2 5}$ & $\mathbf{2 0 3 0}$ \\
\hline Cerrado and Forest & 13.24 & 12.42 & 11.66 & 88.10 & 88.10 & 88.10 \\
\hline Cropland & 64.29 & 65.70 & 67.12 & 9.90 & 9.90 & 10.04 \\
\hline Pasture & 22.25 & 21.65 & 21.00 & 0.21 & 0.21 & 0.08 \\
\hline Legal Int. Scenario & $\mathbf{2 0 2 0}$ & $\mathbf{2 0 2 5}$ & $\mathbf{2 0 3 0}$ & $\mathbf{2 0 2 0}$ & $\mathbf{2 0 2 5}$ & $\mathbf{2 0 3 0}$ \\
\hline Cerrado and Forest & 14.00 & 13.61 & 13.40 & 82.30 & 76.67 & 65.24 \\
\hline Cropland & 63.92 & 64.31 & 64.48 & 7.46 & 12.29 & 23.71 \\
\hline Pasture & 21.86 & 21.86 & 21.89 & 10.04 & 10.04 & 10.04 \\
\hline Illegal Int. Scenario & $\mathbf{2 0 2 0}$ & $\mathbf{2 0 2 5}$ & $\mathbf{2 0 3 0}$ & $\mathbf{2 0 2 0}$ & $\mathbf{2 0 2 5}$ & $\mathbf{2 0 3 0}$ \\
\hline Cerrado and Forest & 17.05 & 16.66 & 16.39 & 69.94 & 66.82 & 64.56 \\
\hline Cropland & 60.58 & 60.97 & 61.23 & 18.14 & 21.20 & 23.46 \\
\hline Pasture & 22.15 & 22.14 & 22.16 & 11.04 & 11.14 & 11.17 \\
\hline
\end{tabular}


Table 2: Optimum calibration parameter values for land use dependent top soil parameters

681

\begin{tabular}{|c|c|c|c|c|c|c|c|}
\hline & \multicolumn{4}{|c|}{ Das Mortes } & \multicolumn{3}{|c|}{ Jamanxim } \\
\hline Land use & $\begin{array}{l}\text { Gallery } \\
\text { forest }\end{array}$ & $\begin{array}{l}\text { Non- } \\
\text { Forest } \\
\text { Pasture }\end{array}$ & $\begin{array}{l}\text { Non- } \\
\text { Forest } \\
\text { Cropland }\end{array}$ & Cerrado & & $\begin{array}{l}\text { Rain- } \\
\text { forest }\end{array}$ & Pasture \\
\hline $\mathrm{CN}$ & 44 & 58 & 48 & 35 & & 36 & 60 \\
\hline $\begin{array}{l}\mathrm{k}_{\text {sat }} \text { Latosolo } \\
\text { vermelho } \mathrm{mm} \mathrm{h}^{-1}\end{array}$ & 183 & & 117 & 262 & $\begin{array}{l}\mathrm{k}_{\text {sat }} \\
\text { Argilosolo } \\
\mathrm{mm} \mathrm{h}^{-1}\end{array}$ & 461 & 453 \\
\hline $\begin{array}{l}\mathrm{k}_{\text {sat }} \text { Latosolo } \\
\text { Vermelho amarelo } \\
\mathrm{mm} \mathrm{h}^{-1}\end{array}$ & 559 & & 407 & 594 & $\begin{array}{l}\mathrm{k}_{\text {sat }} \text { Latosolo } \\
\text { vermelho- } \\
\text { amarelo } \mathrm{mm} \\
\mathrm{h}^{-1}\end{array}$ & 670 & 587 \\
\hline $\begin{array}{l}\mathrm{k}_{\text {sat }} \text { Neosolo } \\
\mathrm{mm} \mathrm{h}^{-1}\end{array}$ & 103 & 120 & & 224 & $\begin{array}{l}\mathrm{k}_{\text {sat }} \text { Neosolo } \\
\mathrm{mm} \mathrm{h}^{-1}\end{array}$ & 221 & 212 \\
\hline
\end{tabular}

682

683

684

685

Table 3: Calibration Statistics for the Model calibration, validation and steady land use application in both study catchments for a monthly time step calibration (coefficient of determination: $R^{2}$, Nash-Sutcliffe Efficiency index: NS, percentual bias: PBIAS, $p$ - and $r$-factor of the $95 \%$ confidence interval)

\begin{tabular}{|l|c|c|l|c|c|c|c|c|c|c|}
\hline & \multicolumn{5}{|c|}{ Das Mortes } & \multicolumn{5}{c|}{ Jamanxim } \\
\hline & $R^{2}$ & NS & PBIAS & $\begin{array}{c}p- \\
\text { factor }\end{array}$ & $\begin{array}{c}r- \\
\text { factor }\end{array}$ & $R^{2}$ & NS & PBIAS & $\begin{array}{c}p- \\
\text { factor }\end{array}$ & $\begin{array}{c}r- \\
\text { factor }\end{array}$ \\
\hline Calibration & 0.85 & 0.74 & -4.54 & 0.84 & 0.87 & 0.8 & 0.8 & -0.5 & 0.60 & 0.47 \\
\hline Validation & 0.79 & 0.73 & -8.1 & 0.91 & 0.86 & 0.8 & 0.8 & 0.8 & 0.42 & 0.63 \\
\hline $\begin{array}{l}\text { steady } \\
\text { land use }\end{array}$ & 0.84 & 0.61 & -16.4 & 0.81 & 0.99 & 0.8 & 0.8 & 1.7 & 0.52 & 0.48 \\
\hline
\end{tabular}


Prediction errors das Mortes catchment
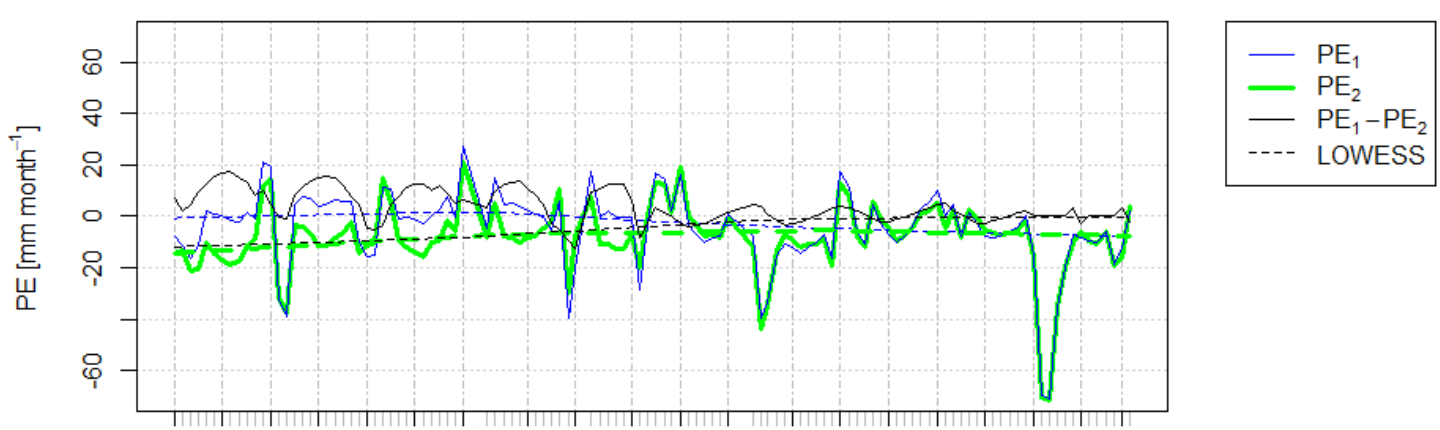

Prediction errors Jamanxim catchment

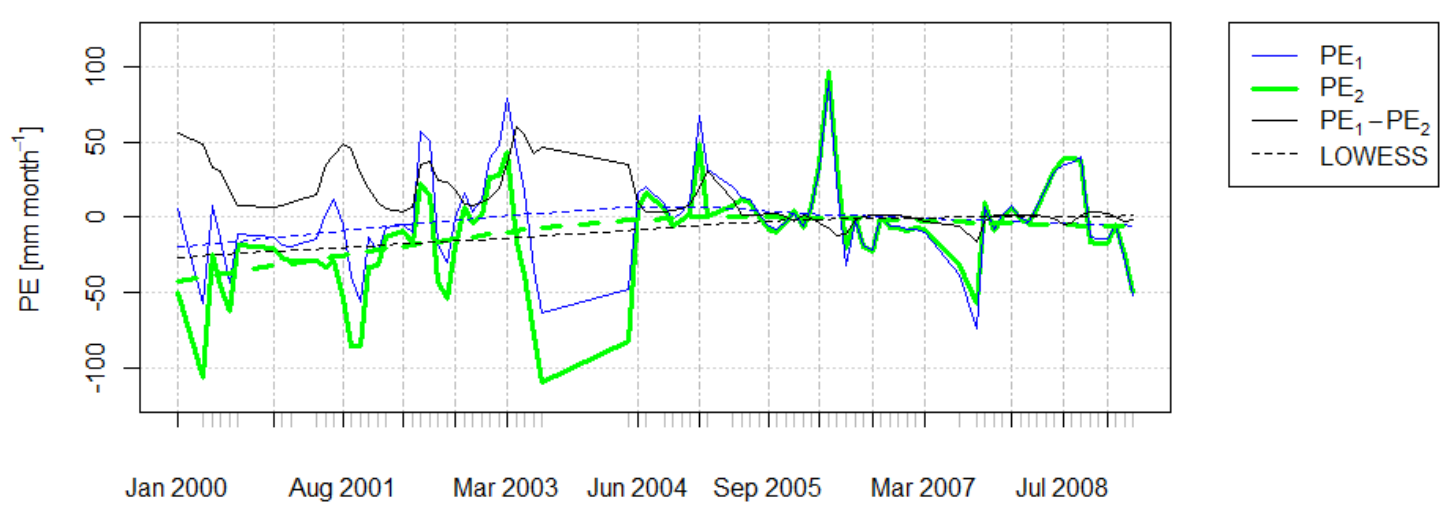

Figure 2 a Das Mortes catchment model, Prediction Error ( $P E=Q$ obs-Qmod) of the land use update $\left(P E_{1}\right)$ and steady land use $\left(P E_{2}\right)$ setup, difference in $P E\left(P E_{1}-P E_{2}\right)$ and LOWESS trend lines of all latter, for the calibration and validation

$2 b$ Jamanxim catchment model, Prediction Error ( $P E=Q o b s-$ $Q m o d)$ of the land use update $\left(P E_{1}\right)$ and steady land use $\left(P E_{2}\right)$ setup, difference in $P E\left(P E_{1}-P E_{2}\right)$ and LOWESS trend lines of all latter, for the calibration and validation

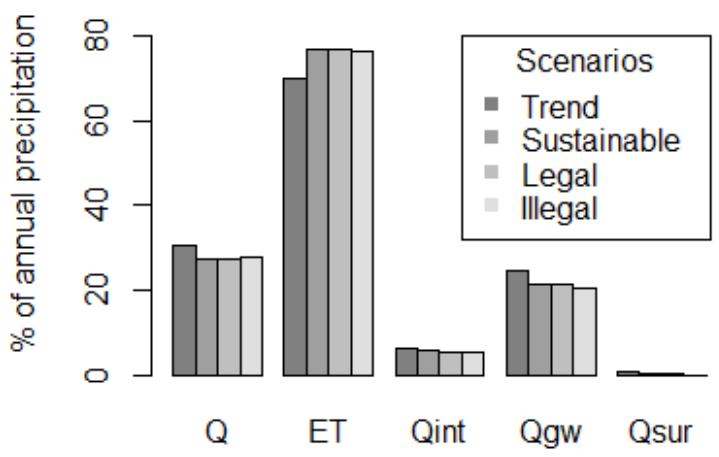

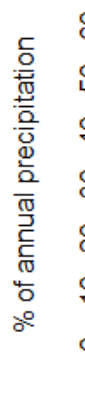

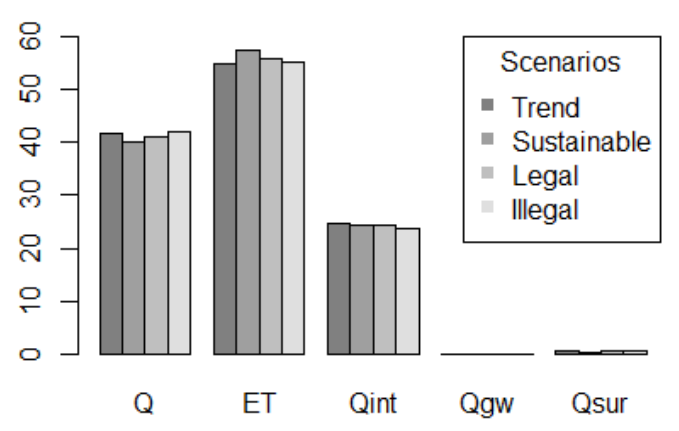

Figure $3 a$ and $b$

Das Mortes catchment; annual water balance components in relation to mean annual rainfall for model scenario period 2026 to 2035, Q: discharge, ET: Evapotranspiration, Qint: interflow from shallow aquifer, Qgw: Groundwater or Baseflow contribution to discharge, Qsur: Surface runoff contribution to discharge 
Jamanxim catchment, annual water balance components in relation to mean annual rainfall for model scenario period 2026 to 2035, Q: discharge, ET: Evapotranspiration, Qint: interflow from shallow aquifer, Qgw: Groundwater or Baseflow contribution to discharge, Qsur: Surface runoff contribution to discharge

\section{Q difference to Trend scenario}

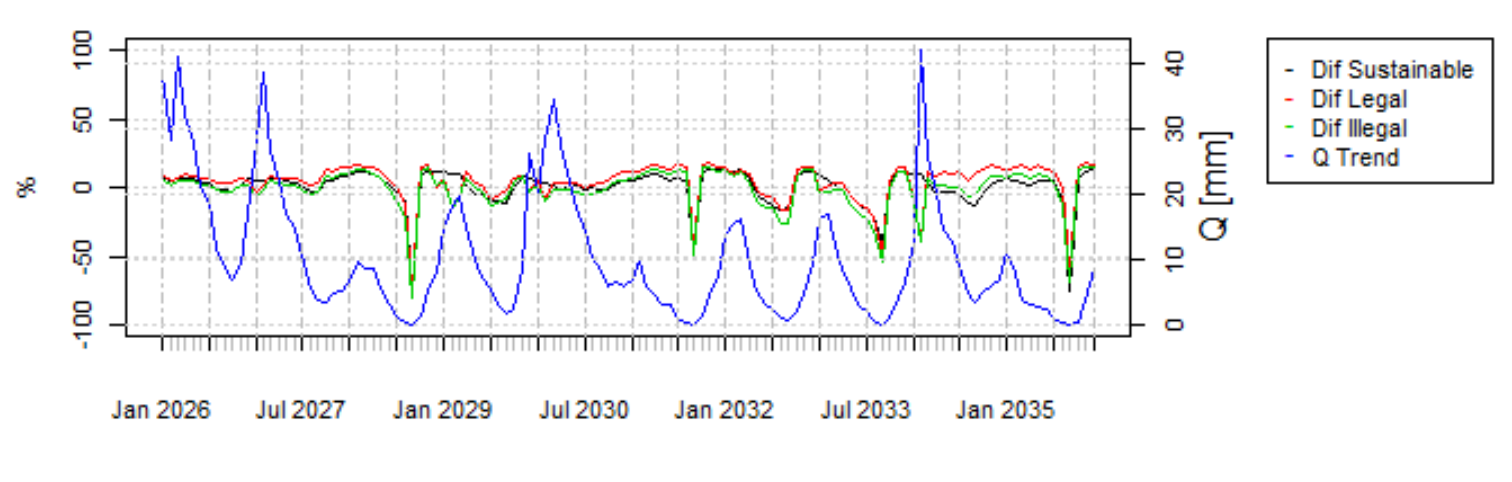

Q difference to Trend scenario

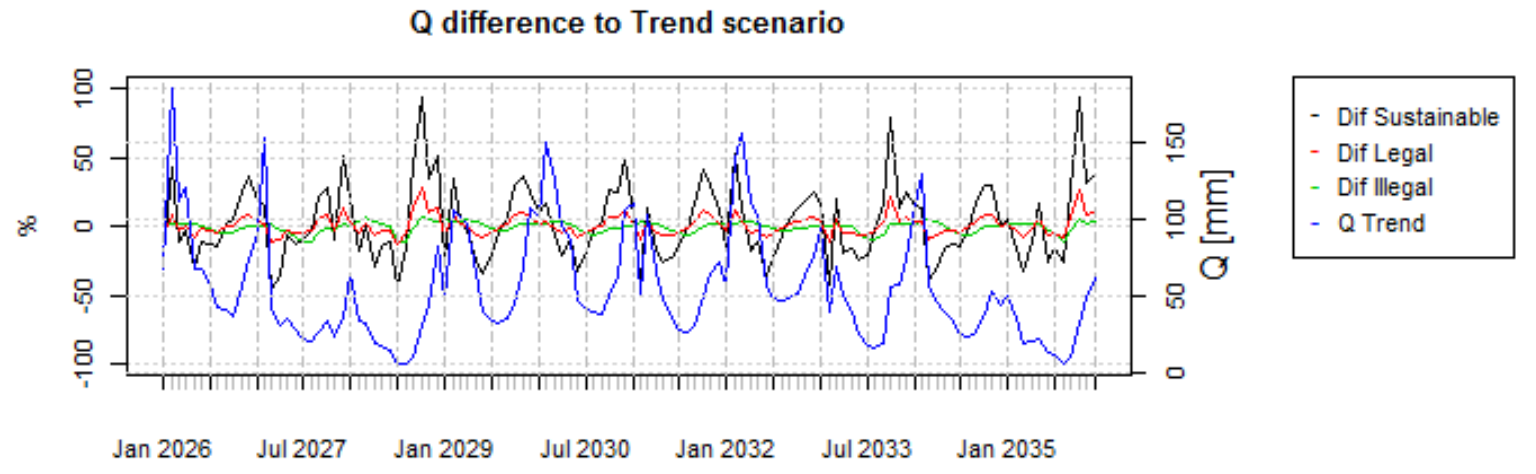

Figure 4 a: Difference in scenario predicted stream discharge: $\Delta Q=Q$ trend-Qother scenarios, and simulated stream discharge for trend scenario, das Mortes catchment

Figure 5 b: Difference in scenario predicted stream discharge: $\Delta Q=Q$ trend-Qother scenarios, and simulated stream discharge for trend scenario, Jamanxim catchment 